\title{
漁村集落における土地利用の変化と津波への対策が 集落空間構成へ与えた影響

\author{
THE EFFECT ON THE SPATIAL COMPOSITION OF A FISHING VILLAGE THROUGH \\ CHANGES IN LAND USE AND COUNTER-MEASURES \\ IN RESPONSE TO THE IMPACT OF TSUNAMIS
}

\author{
佐藤布 武*, 具島桃代**, 橋本 剛*** \\ Nobutake SATO, Momoyo KAIJIMA and Tsuyoshi HASHIMOTO
}

\begin{abstract}
This study aims to reveal traditional measures developed as response against Tsunamis and their impact on the spatial composition of a fishing village previously affected by four Tsunamis since the Meiji era. In order to understand the specific details of each Tsunami event, the study divides and analyzes the village into three areas: "Around the Sea Area " "Around the Houses Area " "Mountain- forest Area". The study reveals the importance not only of the dependence on actual measures but also the importance of taking into account land use strategies derived from the experience of local residents.
\end{abstract}

Keywords: Fishing village, Tsunami, Land use, Transition, Spatial composition, Re-settlement 漁村集落, 津波, 土地利用, 変遷, 空間構成, 再定住

\section{1. はじめに}

日本は四方を海で囲まれた島国であり、多くの漁村集落が存在し ている。なかでも、三陸沿岸部はリアス式海岸という地形的特性か ら大小様々な漁村集落が点在している地域で、気候風土に長い年月 をかけて適応しながら、生業を主とした生活行為の変化の影響を受 けて集落が形成されてきた。そこでは自然環境を集落単位で活用す る自立型の集落生活が営まれており、広大な集落敷地を複数世帯が 共同管理する土地利用がなされてきた。

漁村集落特有の生活環境に関寸る研究は少なくない。それらは、 交通や地形条件などから空間構成を捉える都市スケールのものと、 そこで行われる生活行為と空間の関連を捉える建築・街区スケール のものに大別でき、漁村集落特有の空間的特徴が明らかにされてき

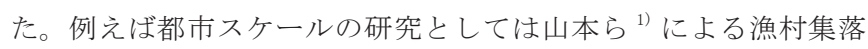
における隣家との間合いの取り方に焦点を当てた研究があり、交通 条件が異なる複数地域の集落構成の比較から漁村における個と集団 の距離感覚を導きだしている。また、長坂 ${ }^{2)}$ は漁村集落の屋外空 間に着眼し、地形形状から分類した集落の経年変化を調查分析する ことで、公共的な機能を含んだ屋外空間「みち」が集落の変化を許 容する柔軟性を有することを明らかにしている。建築・街区スケー
ルの研究には、例えば小泉ら ${ }^{3)}$ の研究がある。小泉らは住民の生 活行為や利用空間に焦点をあて、間取りや住環境、周辺施設の変遷 を捉えることで、住居及び近隣の空間形成を明らかにしている。

三陸沿岸部でも民俗学や生業に関寸る調査が行われており、漁村 集落特有の共同体の存在が指摘されている ${ }^{4) 5}$ 。一方で、三陸沿岸 部は明治以降 4 度の津波被害を経験してきた津波頻発地域でもあ り、津波被害が集落構成一多大な影響を与えている可能性が考えら れる。広範な津波被害と住宅立地の関係を都市スケールから捉えた 研究は比較的多くなされており、甚大な津波被害を受けた地域での 移転後の傾向や問題点が明らかにされている。例えば、山口 ${ }^{6)}$ は ヒアリング調查により明治三陸地震津波 (以下「明治津波」という。) 後の集落移動の実態を把握し、沿岸部への再定住の問題を指摘して いる。また、村尾ら ${ }^{7)}$ は明治津波と昭和三陸地震津波（以下「昭 和津波」という。）被害後の住宅立地を長期的な变遷から捉え、沿 岸部への再定住の傾向を明らかにしている。他に東日本大震災と過 去の津波対策に関して分析したものとして、例えば、沼野ら ${ }^{8)}$ の 研究がある。沼野らは昭和津波で集団移転が実施された大規模集落 を対象に、移転計画地の立地之東日本大震災での被害状況を比較し、 今後の計画地検討の指針を示している。津波被害と漁村集落の構成
* 筑波大学大学院人間総合科学研究科 博士後期課程・修士 (デザイン学)

** 筑波大学芸術系 准教授・修士 (工学)

*** 筑波大学芸術系 准教授. 博士 (工学)
Graduate Student, Graduate School of Comprehensive Human Sciences, Univ. of Tsukuba, M. Des.

Assoc. Prof., Faculty of Art and Design, Univ. of Tsukuba, M. Eng. Assoc. Prof., Faculty of Art and Design, Univ. of Tsukuba, Dr. Eng. 
を建築・街区スケールから捉えた研究としては、例えば、前田ら ${ }^{9)}$ の研究がある。前田らは、インド洋津波被害後の居住者間関係に焦 点を当て、「住宅移転前の従前居住地」住宅移転後の従前居住地」「再 定住地」という 3 箇所の世帯間関係を比較することで、移転前後の 近隣コミュニティの変化を明らかにしている。しかしながら、津波 被害と集落構成との関係を建築・街区スケールから捉えた研究事例 は海外を対象としたものに限られ、都市スケールのものと比べて国 内の事例を調査対象とした研究蓄積は十分ではない。

東日本大震災で三陸沿岸部に位置する多くの集落が甚大な被害を 受けたが、その中には被害が比較的軽微な地域も存在する。一般的 に、津波被害の大きさの差異には集落ごとの立地条件、湾形や方位 などの地理的条件による到達津波高さの影響がある ${ }^{10) 11}$ 。しかしな がら東日本大震災では、多数の漁村集落が近距離に存在する半島部 において、同程度の津波高さでもその被災率には差異が認められる 現象が確認された。その理由として、度重なる自然災害における高 地移転の有無や、その後の低地部への再定住など、土地利用の変化 の違いによる影響の可能性が考えられる。そこで本研究では、生活 行為や土地利用という建築・街区スケールから津波被害とその後の 変化を分析し、津波対策が集落構成へ与えた影響を明らかにするこ とを目的とする。

\section{2. 研究の概要}

\section{1 調査対象集落の選定}

明治以降複数の津波被害とその復興を経験してきた地域である三 陸沿岸部のうち、三方位が海に囲まれていることから被害状況に差 の出やすいと考えられる半島部を抽出し、その中で四方を海または 山に囲まれた独立性の高い集落が多く点在している宮城県石巻市牡 鹿半島を研究対象地域とした。牡鹿半島での東日本大震災の津波に よる被害状況を表 1 に、調査日程を表 2 に示す。まずはじめに、全 集落を対象とした巡見調查により、全集落の被害状況の概要を把握 した。その結果と文献 ${ }^{12)}$ 調查に基づき、図1のように、被災率が 低い集落の中で、半島内の立地や海の方位など、異なる地理的条件 を有する「折浜」「侍浜」「狐崎浜」「新山浜」「泊浜」の 5 つの集落 を第 1 次の悉皆・ヒアリング調查の対象集落として選定した。文献 調查 ${ }^{45)(5) 14)}$ により牡鹿半島での生業や居住環境を把握し、2012 年 5 月から 7 月にかけて 3 回にわたり各集落の歴史や生業空間、地形 的特性に関する概観調查とヒアリング調查を行った。第 2 次調查の 対象集落の選定は、各浜の漁業形態、歴史、防災集団移転促進事業 の有無という視点のもと行った。「新山浜」「泊浜」の 2 集落は、他 の浜への働き手や民宿・釣船経営が多い。そして、狐崎浜」「新山浜」 「泊浜」の 3 集落は、歴史的な古道・金華山街道のルートから外れ ている。また、「折浜」「泊浜」は防災集団移転促進事業の対象地に なっている。以上より、広大な山の敷地を持ち海から山までを連続 的に活用する農山漁村特有の空間的特徵を有するとともに、漁業従 事者の多くが集落の漁場で働いており、古くから利用された金華山 街道 ${ }^{15)}$ が集落敷地内を通る、伝統的な集落である侍浜を第 2 次調 查の対象として選定した。

\section{2 侍浜集落の概要}

調査対象として選定した侍浜集落は三陸海岸の南端、牡鹿半島の 西部に位置し、震災前からカキ養殖業を専門としている漁村集落で

ある。集落は海と山に囲まれた立地で、南面に海、北面に標高 $70 \mathrm{~m}$ 程度の山々、北東部に標高 $358.6 \mathrm{~m}$ の袴田岳がある。集落は北西の 風を避けるために西部から居住を始めたと言われている。平地面積 が限られているため、最も栄えていたとされる明治初期で 17 世帯、 東日本大震災前の人口は 10 世帯 38 人という小さな集落である。山 間部に石垣の段を設け農地とした形跡が残るなど、地形的な制限の ある集落敷地を有効に活用してきたことが確認できる。図 2 に示す ように、峠を越えて隣浜に至る山道は、古くから金華山への参拝道 金華山街道として多くの人々に利用されていた。

表 1 各集落の津波被害状況

\begin{tabular}{|r|l|c|c|r|}
\hline & 集落名 & $\begin{array}{c}\text { 被害 } \\
\text { 数 }\end{array}$ & 残存 & 被災率 \\
\hline 1 & 小竹浜 & 14 & 40 & $25.9 \%$ \\
\hline 2 & 折浜 & 4 & 14 & $22.2 \%$ \\
\hline 3 & 蛤浜 & 4 & 5 & $44.4 \%$ \\
\hline 4 & 桃浦 & 60 & 2 & $96.8 \%$ \\
\hline 5 & 月浦 & 33 & 2 & $94.3 \%$ \\
\hline 6 & 侍浜 & 2 & 9 & $18.2 \%$ \\
\hline 7 & 荻浜 & 55 & 2 & $96.5 \%$ \\
\hline 8 & 小積浜 & 16 & 7 & $76.2 \%$ \\
\hline 9 & 牧浜 & 12 & 11 & $52.2 \%$ \\
\hline 10 & 竹浜 & 9 & 3 & $75.0 \%$ \\
\hline 11 & 狐崎浜 & 2 & 25 & $7.4 \%$ \\
\hline 12 & 鹿立屋敷 & 11 & 0 & $100 \%$ \\
\hline 13 & 福貴浦 & 16 & 19 & $45.7 \%$ \\
\hline 14 & 小網倉浜 & 44 & 12 & $78.6 \%$ \\
\hline 15 & 大原浜 & 70 & 22 & $76.1 \%$ \\
\hline 16 & 給分浜 & 44 & 34 & $56.4 \%$ \\
\hline 17 & 小淵浜 & 130 & 39 & $81.8 \%$ \\
\hline 18 & 十八成浜 & 90 & 37 & $70.9 \%$ \\
\hline 19 & 鮎川浜 & 376 & 326 & $53.8 \%$ \\
\hline 20 & 新山浜 & 0 & 34 & $0 \%$ \\
\hline 21 & 泊浜 & 19 & 41 & $31.7 \%$ \\
\hline 22 & 祝浜 & 8 & 0 & $100 \%$ \\
\hline 23 & 谷川浜 & 55 & 1 & $98.0 \%$ \\
\hline 24 & 大谷川浜 & 26 & 0 & $100 \%$ \\
\hline 25 & 鮫浦 & 28 & 0 & $100 \%$ \\
\hline 26 & 奇磯浜 & 60 & 40 & $58.3 \%$ \\
\hline 27 & 前網浜 & 18 & 5 & $78.3 \%$ \\
\hline & & & \\
& & &
\end{tabular}

表 2 調查日程一覧

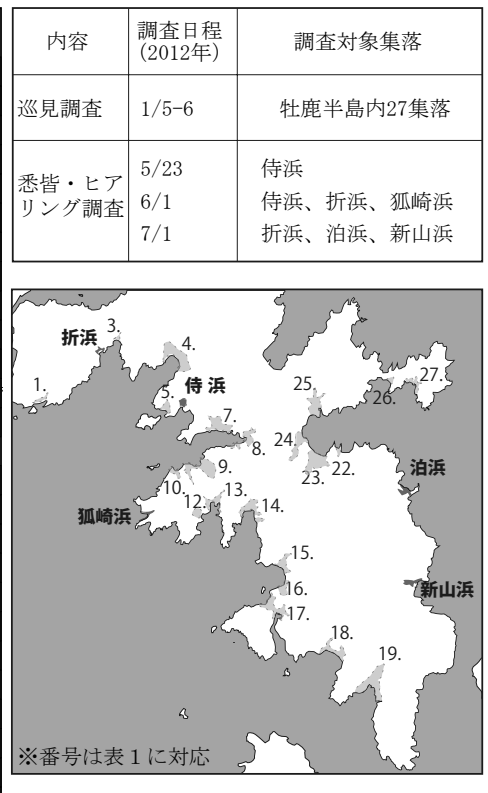

図1 牡鹿半島集落分布図

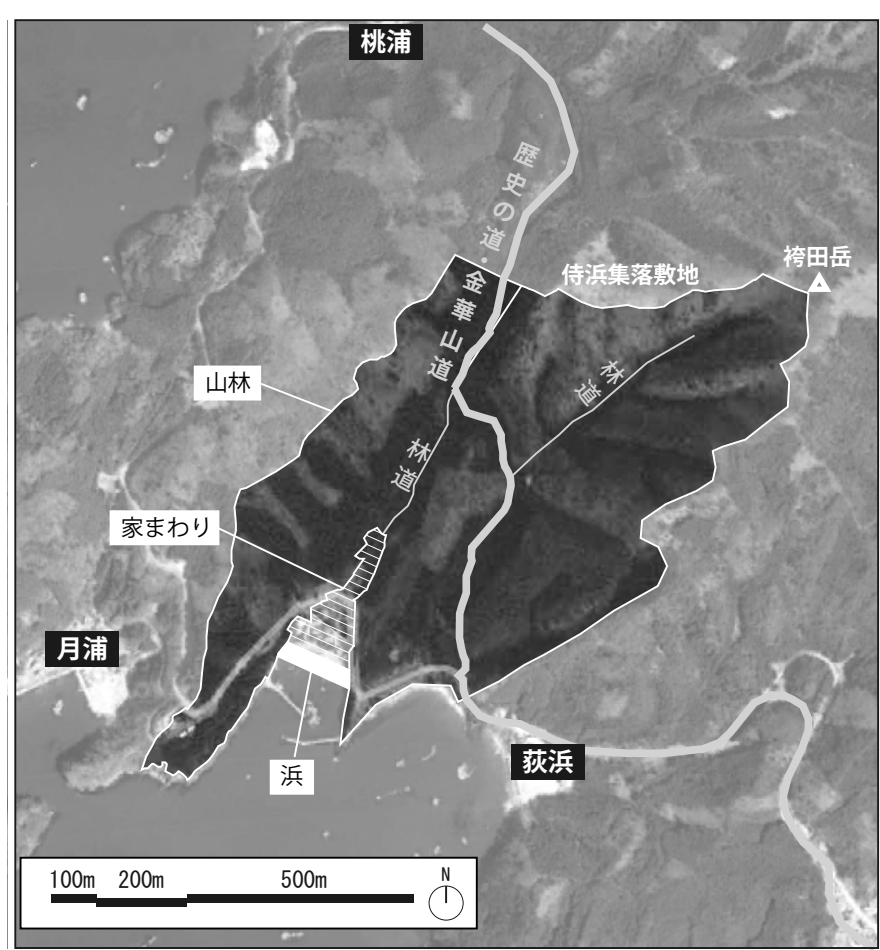

図 2 侍浜集落敷地状況 


\section{3 研究方法}

本研究は、度重なる津波被害を経験することで集落空間構成がど のように変化してきたのかを、各時代の土地利用とその変遷から捉 えることを目的としている。そこで表 3 に示すように、三陸地方で 過去に起こった 4 回の津波を基準に時代を 5 つに区分した。また、 図 2 のように、集落敷地内を海とその周辺の生産空間を「浜」、宅 地利用と畑利用がみられる生活空間の「家まわり」それ以外の「山 林」という 3 つの領域に大別し、土地利用の分析を試みる。

集落空間構成の分析に使用した資料を表 3 に示す。各年代の集落 空間構成の把握には公図、地籍図、空中写真 ${ }^{16)}$ を使用した。津波 被害はそれぞれの津波被害報告書 ${ }^{17718) 19)}$ により概略を把握し、石 巻の歴史 ${ }^{20)}$ で近隣集落における被害状況を捉えた。その後、侍浜 での被害状況を把握するため、旧土地台帳の調査を行った。土地の 所有を公図と旧土地台帳から捉えた後、表 4 に示すように、集落内 民家の全軒実測調查と昔の間取りの調查を 2012 年 5 月と 9 月に行っ た。また、ヒアリング調查を 2012 年 9 月、10月、11月の 3 期に分 けて行った。ヒアリングはインタビュー形式で行い、調查票を持っ て各世帯を個別に訪問した。調查内容は、時代区分ごとの民家空間 や浜、山林の利用方法およびその变化などとした。ヒアリングに際 し、「c-2」は東日本大震災後に借家として入居した住民のため対象 から除外した。 5 月と 9 月の調查では、各世帯を訪問し住宅の間取 りを確認した後、世帯主へのヒアリングを 1 時間程度行い、住宅の 使い方や建設年代、住宅建設当時の周辺環境などを確認した。10 月の調查は生活実態 ${ }^{45) 21)}$ や漁業形態 ${ }^{13) 14)}$ に関する文献を事前に調 查した後、高齢の 3 世帯を対象に 1 時間から 2 時間程度行い、祭事 や過去の漁業活動、津波被害後の集落の変化を確認した。11月の 調查では再び全世帯を訪問し、山林利用に関する調查を 1 持間程度 行った。

\section{1886 年明治初期の居住形態}

\section{1 各領域における土地利用}

この時代における侍浜では、他の集落や市街地に依存しない自立 型の生活を営み、農家、林家、網職人、炭職人など多様な職業を持 つ人々が居住していた。

(1) 浜

侍浜では湾内にて集落単位で行う「大網」注1) が主な漁業形態で、 1 世帯の地主兼網元 (以下、「地主」という。) を中心とした集落単 位で行ったため、漁業活動は浜で完結していた。

(2) 家まわり

図 3 に 1886 年時点の家まわりでの土地利用を示す。当時は宅地を、

表 3 集落構成分析に際する使用データ

\begin{tabular}{|c|c|c|c|c|c|c|}
\hline & 時代 & 地図 / 空中写真 & 津波被害報告書 & \begin{tabular}{|l|} 
石巻の \\
歴史
\end{tabular} & \begin{tabular}{|c|} 
旧土地 \\
台帳
\end{tabular} & $\begin{array}{l}\text { ヒアリ } \\
\text { ング }\end{array}$ \\
\hline 第3章 & 明治初期 & 地籍図 (1886年) & & & $\bigcirc$ & \\
\hline 第4章 & \begin{tabular}{|l|l|}
1896 年 \\
明治津波以降
\end{tabular} & & $\begin{array}{l}\text { 1896年明治三陸地震 } \\
\text { 津波報告書 }\end{array}$ & $\bigcirc$ & $\bigcirc$ & $\bigcirc$ \\
\hline 第5章 & $\begin{array}{l}\text { 1934年 } \\
\text { 昭和津波以降 }\end{array}$ & 空中写真(1947年) & 三陸沖強震及津浪報告 & $\bigcirc$ & $\bigcirc$ & O \\
\hline 第6章 & \begin{tabular}{|l|} 
1960年チリ地震 \\
津波以降
\end{tabular} & \begin{tabular}{|l|} 
空中写真 \\
(1967年と1975年)
\end{tabular} & チリ地震記念三陸津波誌 & $\bigcirc$ & $\bigcirc$ & $\bigcirc$ \\
\hline 第7章 & $\begin{array}{l}\text { 2011年東日本 } \\
\text { 大震災以降 }\end{array}$ & 空中写真 (2011年) & & & & $\bigcirc$ \\
\hline
\end{tabular}

表 4 調查対象住宅一覧

\begin{tabular}{|c|c|c|c|c|c|c|c|c|c|c|c|c|c|c|c|c|c|}
\hline & \multicolumn{8}{|c|}{ 住宅調査 } & \multicolumn{8}{|c|}{ ヒアリング調査 } & \multirow{3}{*}{$\begin{array}{c}\text { 調査日程 } \\
\text { 住宅 | ヒアリング }\end{array}$} \\
\hline 資 & \multirow{2}{*}{$\begin{array}{l}\text { 建 } \\
\text { 設 } \\
\text { 年 } \\
\text { 代 }\end{array}$} & \multirow{2}{*}{\begin{tabular}{|l|} 
害 \\
睮 \\
無 \\
\end{tabular}} & \multirow{2}{*}{$\begin{array}{l}\text { 外 } \\
\text { 観 } \\
\text { 調 } \\
\text { 查 }\end{array}$} & \multirow{2}{*}{$\begin{array}{l}\text { ア間 } \\
\text { リ取 } \\
\text { り } \\
ク ゙ ヒ\end{array}$} & \multirow{2}{*}{\begin{tabular}{|l|} 
娄 \\
面 \\
供 \\
\end{tabular}} & \multirow{2}{*}{\begin{tabular}{|l|} 
外 \\
観 \\
查 \\
\end{tabular}} & \multirow{2}{*}{ 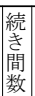 } & \multirow{2}{*}{\begin{tabular}{|l} 
畑 \\
地開 \\
拓
\end{tabular}} & \multirow{2}{*}{\begin{tabular}{|l} 
居 \\
集 \\
無 \\
\end{tabular}} & \multicolumn{3}{|c|}{ 世世带主情報 } & \multicolumn{4}{|c|}{ 津波後の変化 } & \\
\hline $\begin{array}{l}\text { 料 } \\
\text { 番 }\end{array}$ & & & & & & & & & & $\begin{array}{l}\text { 年 } \\
\text { 齢 }\end{array}$ & 性 & $\begin{array}{l}\text { 職 } \\
\text { 嶪 } \\
\text { 等 }\end{array}$ & $\begin{array}{l}\text { 明 } \\
\text { 治 }\end{array}$ & \begin{tabular}{|l} 
照 \\
和
\end{tabular} & \begin{tabular}{|l} 
于 \\
y
\end{tabular} & $\begin{array}{l}\text { 東 } \\
\text { 本 }\end{array}$ & \\
\hline$\overline{a-1}$ & 明治期 & 0 & & & & $\triangle$ & 4 & & & & & & & & & & $9 / 16-17 \mid-$ \\
\hline $\mathrm{a}-2$ & 1953年 & 0 & & & & & 3 & 0 & & & & & & & & & $9 / 18.11 / 16 \mid-$ \\
\hline $\mathrm{b}-2$ & 1955年 & 0 & & & & & 3 & 0 & & & & & & & & & $9 / 18 \mid-$ \\
\hline$a-3$ & 1960年 & 0 & & & & $\triangle$ & 3 & 0 & & & & & & & & & $9 / 17 \mid-$ \\
\hline$b-1$ & 1960年 & 0 & & & & & 3 & & 0 & 80 代 & 男 & 区長 & 0 & 0 & 0 & 0 & $\begin{array}{l}5 / 23 \mid 9 / 19.10 / 19.11 / 18 \\
\end{array}$ \\
\hline$c^{-1}$ & 1961年 & 0 & & & & & 3 & & O & 50 代 & 男 & 漁師 & & & 0 & & \begin{tabular}{|l|}
$9 / 16 \mid 9 / 1.11 / 16$ \\
\end{tabular} \\
\hline $\mathrm{d}$ & 1961年 & & 0 & 0 & & & 2 & 0 & & & & & & & & & \\
\hline $\mathrm{e}$ & 1961年 & 0 & & & & & 2 & & 0 & 50 代 & 女 & $\begin{array}{c}\text { 無職 } \\
\end{array}$ & & & & & $\begin{array}{l}9 / 16 \mid 9 / 16.11 / 19 \\
\end{array}$ \\
\hline$c-2$ & 1965年 & 0 & & & & & 3 & & ※ & & & & & & & & $9 / 18 \mid-$ \\
\hline $\mathrm{c}-3$ & 1967年 & O & & & & & 2 & 0 & & & & & & & & & $9 / 17 \mid-$ \\
\hline $\mathrm{f}$ & 1967年 & 0 & & & & & 3 & & 0 & 60 代 & 男 & 漁師 & & 0 & 0 & & $9 / 17 \mid 9 / 19 \cdot 10 / 21.11 / 16$ \\
\hline $\mathrm{b}-3$ & 1978年 & 0 & & & & & 2 & 0 & 0 & 60 代 & 男 & 漁師 & & 0 & 0 & & $9 / 16 \mid 9 / 16.11 / 20$ \\
\hline $\mathrm{a}-4$ & 1979年 & & 0 & $\mathrm{O}$ & & $x$ & 1 & & & & & & & & & & \\
\hline $\mathrm{c}-4$ & 1988年 & 0 & & & & & 2 & 0 & 0 & 60 代 & 男 & 漁師 & & 0 & 0 & & $9 / 16 \mid 9 / 20.10 / 20.11 / 19$ \\
\hline $\mathrm{a}-5$ & 1989年 & & 0 & 0 & & $x$ & 2 & & & & & & & & & & \\
\hline $\mathrm{g}$ & 1990年 & 0 & & & & $x$ & 3 & & & & & & & & & & \\
\hline$a-6$ & 1998年 & & & & O & & 1 & 0 & 0 & 50 代 & 男 & 地主 & 0 & & & & \begin{tabular}{l|l|}
-17 \\
\end{tabular} \\
\hline
\end{tabular}

$\triangle$ : 地震による全壊 $x$ : 津波による流出 $※:$ 東日本大震災後の転入

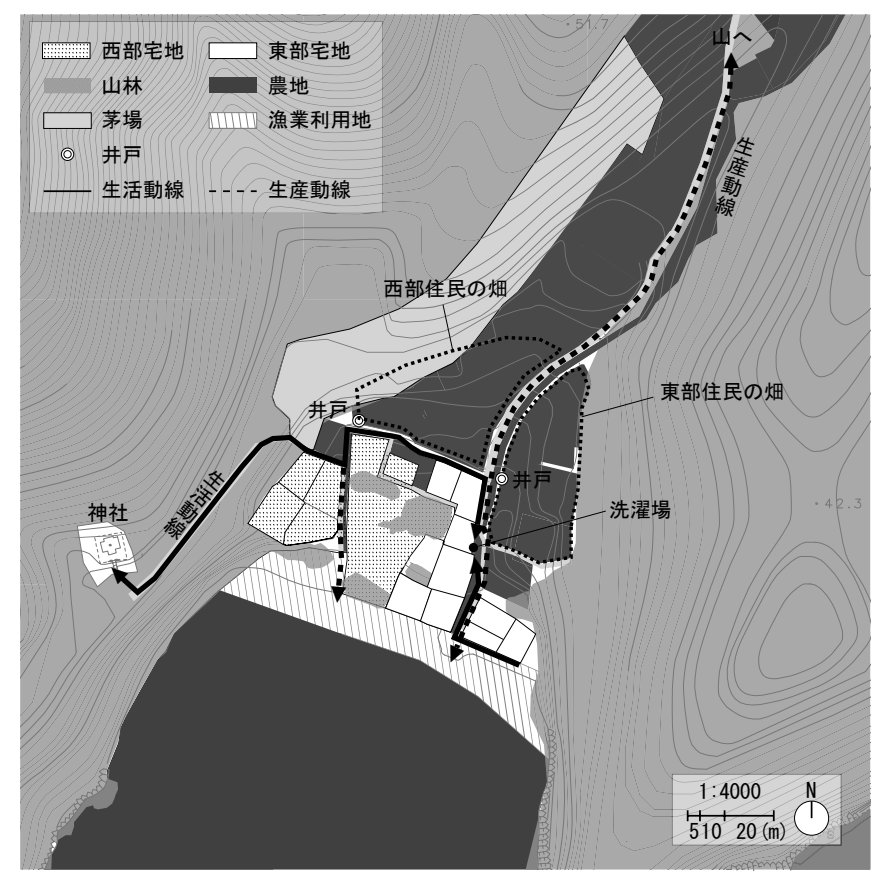

図 3 明治初期の家まわりでの土地利用

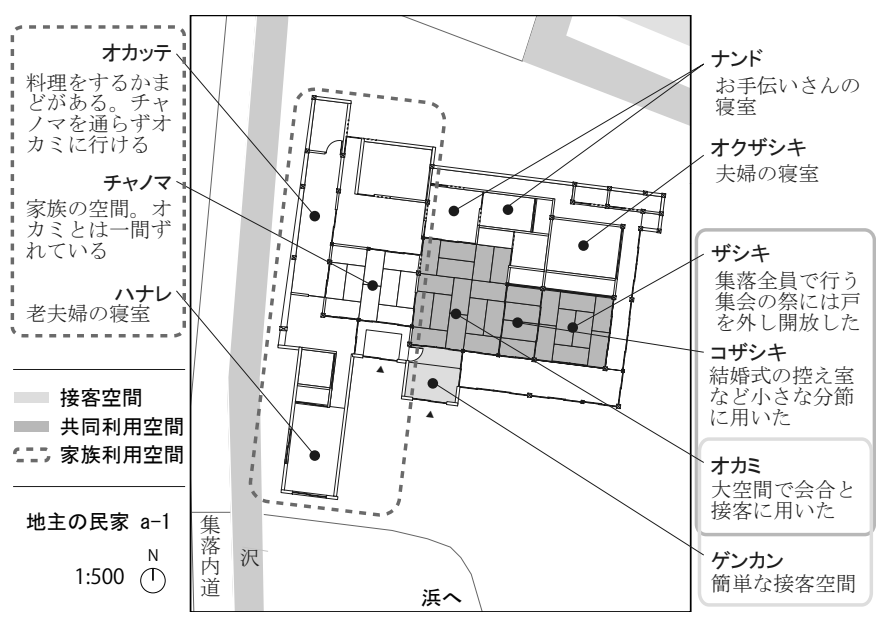

図 4 地主民家の間取りとその使い方（1886 年） 
井戸よりも低地で沢や海へ排水できる場所に設置していた。そのた め、宅地と畑は取水と排水を共同寸る東部と西部に大別できた。ま た、集落動線には神社から洗濯場までをつなぐ東西生活動線と、海 から山林までの南北生産動線が存在していた。

明治初期の民家は、大規模な地主民家（図 4）と一般民家（図 5） があった。漁業を集落全体で行っていたため多くの会合を地主民家 のオカミで行った。また、一般民家でも冠婚葬祭が行えるオカミと ザシキの続き間という、共同利用空間が設えられていた。

(3) 山林

図 6 に示すように、侍浜の山林の大部分は地主が所有していた。 家まわりから離れた北東部のみ地形に合わせて分割し、それぞれの 世帯が各々個別に所有していた。各世帯の所有は集落に近い部分を 古くからの住民である西部住民が、遠い部分を東部住民が所有し、 余った土地を地主が所有している。山林の利用には 4 種類の目的が 存在した。家まわりに近い谷沿いを「a. 建材」、遠い部分や急峻な 斜面、を「b。燃料資源」として活用し、林道沿いは農家が管理す る段状の「c．農地」として活用した。それ以外に、「b. 燃料資源」 のある雑木林や道沿いでは「 $\mathrm{d}$. キノコや山菜などの採集」も行っ ていた。「a. 建材」は地主から購入する形式を取り、建設や解体、 林道整備など、人手を要する際は集落民総出で協力して行った。一 方で、日常的に活用する「b. 燃料資源」と「d.キノコや山菜など の採集」に関しては所有に関わらず山林を自由に利用でき、利用す る頻度によって集落内の取り決めが異なっていた。

\section{2 土地利用の特徵}

明治初期の特徽を捉えるため複数世帯の共同利用を領域ごとに抽 出し、所有と利用母体から表 5 のように整理した。表 5 の着色部分 に示すように、「浜」「家まわり」「山林」のいずれの領域でも所有 と利用が一致しないことが明らかになり、侍浜では集落や地主が所 有しているものを集落民が自由に活用するという特徴が示された。 更に、表 6 のように利用母体と利用頻度のマトリクス図を作成し、 3 つの類型を抽出した。日常的なものは、広大な土地全体を地主や 集落単位で所有し、その資源を集落民が共同利用するものである。 地理的条件によるものは、家や畑、山林などの、所有敷地の隣接や 動線との関係に起因するもので、近隣付き合いの形成に寄与してい たものと推察される。非日常的なものは集落全体で行われたもので、 集落の人間関係を形成する上で重要であったと考えられる。

\section{1896 年明治津波以降の居住形態}

\section{1 被災状況とその対策}

明治津波は、1896 年 6 月 15 日午後 7 時 32 分に現釜石市の東方 沖 $200 \mathrm{~km}$ を震源として発生した地震による津波で、石巻市鮎川で の観測記録によると、午後 8 時 30 分に津波の第 1 波が来襲したと される。三陸沿岸全体で、死者 26761 人、負傷者 4398 人、流出家 屋 10370 棟などの被害だった。明治津波からの復興では、国や県が 主導して移転させる事例は見られず、各地の有力者が宅地造成して 集落で宅地を移転する場合や世帯ごとに移転する場合がほとんどで あった ${ }^{20)}$ 。侍浜でみられる移転も後者であったとされる。

\section{2 震災後の各領域における土地利用}

(1) 浜

明治三陸津波の前年の 1895 年に、漁業技術が著しく改良されて
いる。それは、鰯網の改良を続けていた牡鹿半島谷川浜の石森善左 衛門が、省力化の可能な水晶型器械網を考案し、数年のうちに太平 洋沿岸一帯に普及させたというものである ${ }^{22)}$ 。津波で漁具倉庫や 漁具に被害があった侍浜でもこの技術改良が導入され、少ない人数
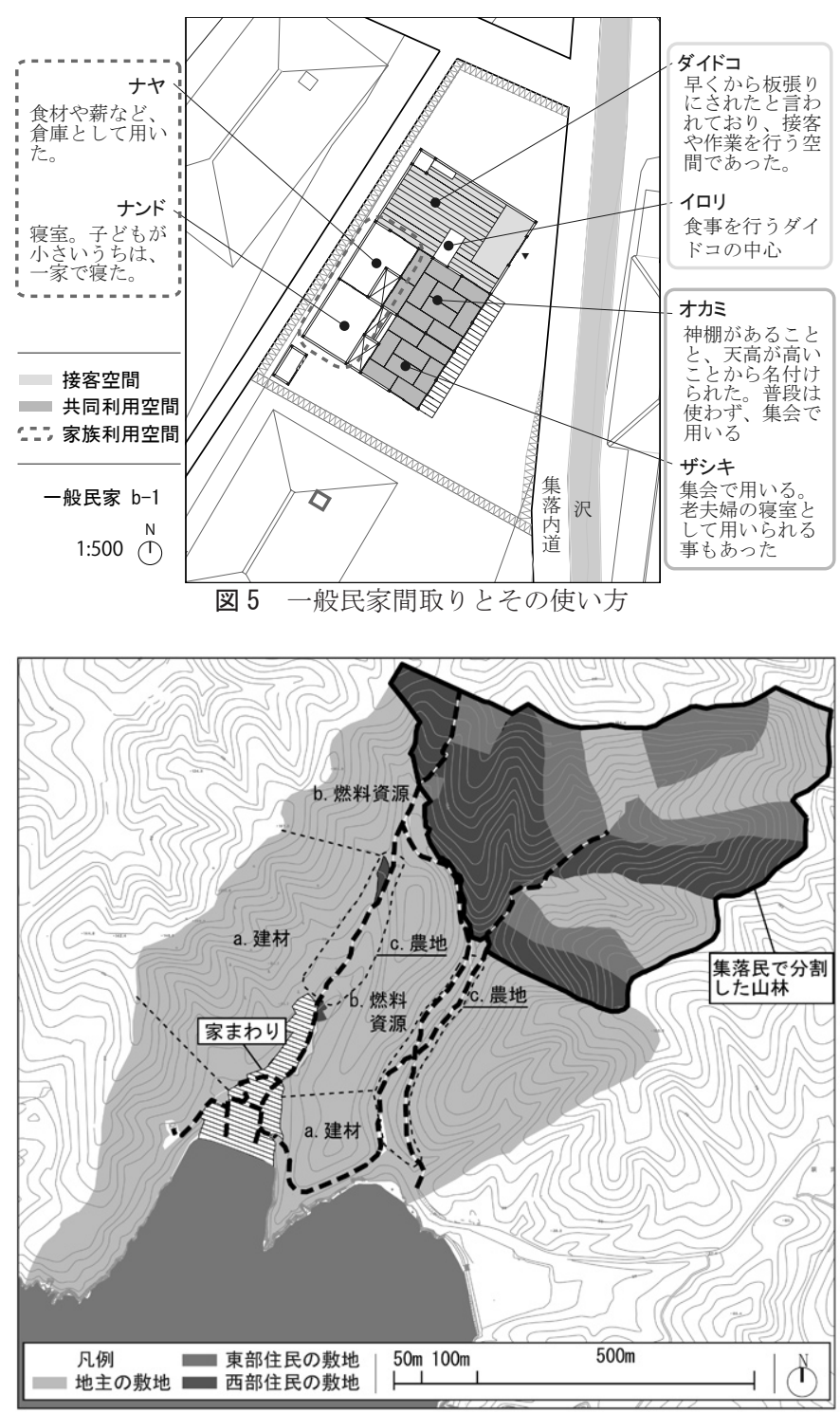

図 6 明治初期の山林の土地所有

表 5 領域ごとの所有と利 用の関倸 (明治初期)

表 6 利用母体と頻度の関係からみ

\begin{tabular}{|c|c|c|c|}
\hline & 行為 & 土地所有 & 利用母体 \\
\hline \multirow[b]{2}{*}{ 浜 } & 地先網漁 & 集落 & 集落 \\
\hline & 磯物 & 集落 & 各世帯 \\
\hline \multirow{8}{*}{ 家护 } & 水汲み & 集落 & 東西住民 \\
\hline & 洗濯 & 集落 & 各世帯 \\
\hline & 冠婚葬祭 & 各世带 & 集落 \\
\hline & 祭事 & 地主 & 集落 \\
\hline & 世間話 & 各世帯 & 東西住民 \\
\hline & 民家建設 & 各世帯 & 集落 \\
\hline & 訪問 & 各世帯 & 東西住民 \\
\hline & 畑仕事 & 各世帯 & 東西住民 \\
\hline \multirow{4}{*}{ 山 } & 薪拾い & 地主 & 各世帯 \\
\hline & 山菜採り & 地主 & 各世帯 \\
\hline & 林道整備 & 集落 & 集落 \\
\hline & 建材利用 & 地主 & 各世帯 \\
\hline
\end{tabular}
た土地利用の特徵（明治初期）

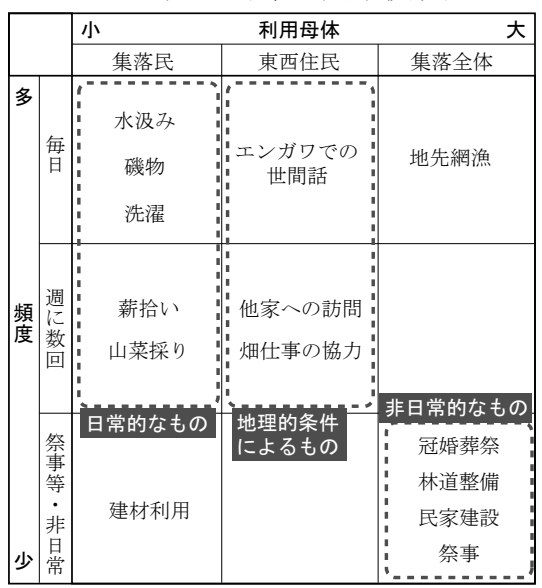


での操業が可能なこの漁法を採用したとされている。その際、新し く入手した漁具はエンガワで保管するようになり、また、網の修繥 作業なども民家で行うようになった。そのため、エンガワが浜の仕 事の作業空間となった。

(2) 家まわり

図 7 に示すように、明治津波直後に低地に位置する 3 世帯の宅地 移転が確認でき、土地の高低差を考慮するとそれ以外に 2 世帯で移 転を要しない程度の被害があったと推測される。宅地移転は集落規 模ではなく、被災世帯が所有する畑地を宅地に変更することによる 移転であった。

(3) 山林

2012 年の調查時点で集落に残存していた民家の中で、最も古い 1950 年代までに建てられた 3 軒が、寸心゙て集落山林の建材を利用 していることから、明治津波後の移転でも山林資源を利用したもの と推測される。家や小屋を建てる際には侍浜の木材を活用し、集落 全員で解体・上棟作業を行っていた。つまり、山林利用の「a. 建材」 が津波被害に対する集落の備えとして、機能していた。

\section{3 土地利用の特徵}

土地利用は明治津波前と大きく変化はなかった注2)。図 8 に示寸 ように、震災で被害を受けた民家や漁具倉庫の再建に集落の建材を 活用し、震災後はこれまで浜で行っていた漁具の保管や軽作業をエ ンガワで行うようになった。また、山菜や畑、燃料材は非常時にお ける集落民の生活を助けるものでもあった。こうした海から山まで の広大な集落敷地の連続的な活用は、災害に対する備えとしても重 要であったと考えられる。

\section{1934 年昭和三陸地震大津波以降の居住形態 5. 1 被災状況とその対策}

昭和津波は、1933 年 3 月 3 日午後 2 時 30 分に岩手県沖で発生し た地震によるもので、被害は宮城県から北海道までの太平洋沿岸地 域に渡り、死者 1726 人、傷者 1052 人、行方不明 1282 人、流出家 屋 4917 棟などであった。津波規模自体は明治のものと同等であっ たが、1896 年の明治津波の経験から津波を警戒していたため、そ の被害は小さかったとされている。石巻地域では雄勝町荒で $10 \mathrm{~m} の$ ものが最大で、現石巻市大原や谷川などの太平洋沿岸の被害が大き く、それ以外の石巻湾に面した地域の被害は比較的小さかった ${ }^{20)}$ 。

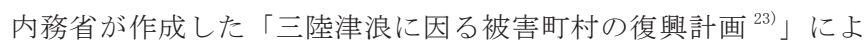
ると、規模や被害が大きい集落は復興事業の多くを国庫補助などで 賄ったが、規模や被害が小さな集落は自力での復興が促進されてい る。石巻市内では三陸沖強震及津浪報告 ${ }^{18)}$ に基づく復興計画がな された。

以下にその復興計画を記す。

1. 防波堤 : 湾口よりも海岸の方が良い

2. 防波林の設置

3. 防潮楼 : 湾口の巨浪を確認してから避難しても間に合う

4. 地盤を高めること：盛土も効果あり

5. 避難道路 : 付近の丘上へ逃げる道の整備

6. 住宅を高所に移す：職業によって不便な場合もある 侍浜においては、2. 防波林が集落で実施された。

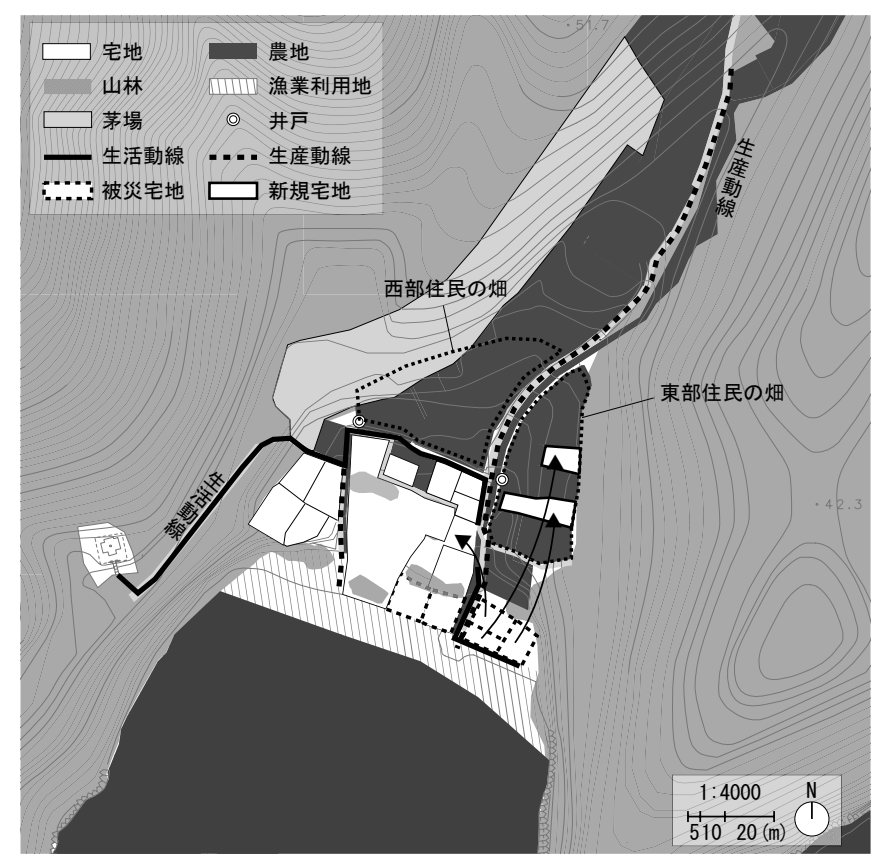

図 7 明治津波後の家まわりでの土地利用

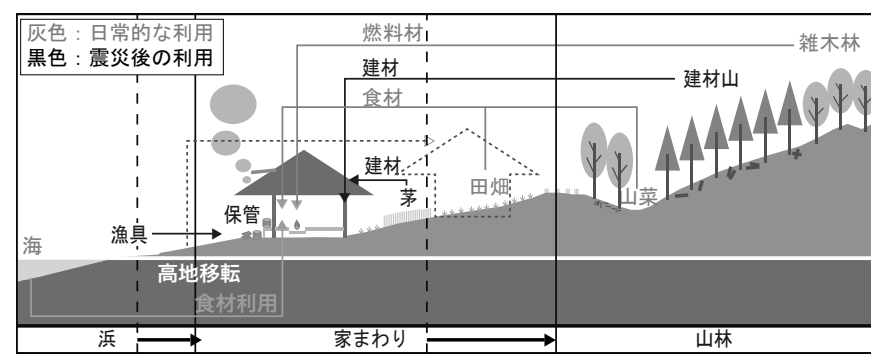

図 8 明治津波復興における集落構成の変化と集落資源の活用

\section{2 震災後の各領域における土地利用}

(1) 浜

震災後も浜の利用方法は変わらなかった。震災前の1931 年から カキ養殖と種力キの採苗が隣浜の荻浜で開始されていたが、侍浜で は縄や漁法の改良が行われた ${ }^{14)}$ のちの 1949 年に導入された。生業 が変化しなかった理由として、漁具の保管は民家のエンガワを利用 していたため津波被害が少なかったこと、これまで行っていた漁法 が初期投資の少ないものであったことが考えられる。力キ養殖業は 1950 年に 2 世帯、1960 年のチリ津波前に 4 世帯が行っていた。家 まわりに設けた竹林で䇝を作成し、内湾の波が穏やかな場所で行う 養殖法で、図 9 に示すように、出荷前のカキ剥き作業を各世帯が保 有する「カキ剥き場」と呼ばれる 2 間 $\times 3$ 間程度の小さな倉庫で各々 行っていた。カキ剥き場を所有していない場合や新しくカキ剥きを 始める場合は、一回り大きな地主のカキ剥き場を間借りし修業を受 ける仕組みであった。土地の利用は、倉庫と剥き場を各自で所有し、 作業場を共同するものとなった。

(2) 家まわり

津波による直接的な被害は確認できなかった。これは、明治の津 波被害で得た教訓として、浸水域を集落の有力者であった 2 世帯が 所有し、民家を建てないようにしていたことに起因すると考えら れる。また、図 9 に示すように、集落として復興計画の「2. 防波 林」が行われた。それは、集落西部の斜面を削り地主敷地南面に石 
垣と防波・防風林を設置する整備で、1955 年頃に行われた。また、 1924 年から墓地整備と隣接集落間の県道整備が行われ、道の南部 を各世帯が利用する畑、北部が集落外一販売するための農地とした。

1953 年と 1955 年に行われた新築は、高地に位置する畑地を宅地 化するものだった。その後 1960 年から、明治時代に建てられた既 存民家の建て替えが行われた。これらの民家間取りは共通しており、 室の細分化がみられた。図 10 に示寸ように、これまでのダイドコ 空間が、家事を行う「オカッテ」、家族のだんらんや食事を行う「チャ ノマ(2)」及び接客を行う「チャノマ」の 3 室に分割された。「チャ ノマ」「オカミ」「ザシキ」が桁行方向に三間続く間取りで「チャノ マ（2）」「オカッテ」「オクノマ」が背後に位置する構成をとる。奥 の室群は家族が利用し、手前の室群は集落で共同利用した。

(3) 山林

木材価格の高騰に伴い 1950 年代後半から侍浜でも植林が行われ、 杉林が増加した。民家建設に集落建材が使われたのは、1960 年の ものが最後で、それ以降の 1960 年代に行われた民家建て替えでは 集落建材は活用せず、林家が生産した建材は集落外で販売されるよ うになった。一方で、「b. 燃料資源」「c．農地」「d．キノコや山菜 などの採集」としての山林利用は継続して行われた。

\section{3 土地利用の特徵}

震災後漁業形態の変化は見られず、家まわりへの直接的な被害も なかったため、大きな変化は生じなかった。変化が見られたのはカ キ養殖導入以降である。表 7 及び表 8 に昭和津波後の共同利用を示 す。明治期の類型が維持される一方で、漁業で用いる竹林の活用や 作業場でみられるように、常に使うわけではないものは個人で管理 するよりも集団で管理した方が効率的なため、共同で管理し順々に 利用した。

\subsection{0 年チリ地震津波以降の居住形態}

\section{1 被災状況とその対策}

チリ地震津波（以下、「チリ津波」という。）は、南米チリの中部 西海岸で 5 月 23 日午前 4 時 15 分頃（日本時間）に発生した地震に よる津波が太平洋を渡って日本まで到達したもので、被害は全国で 死者 100 人、負傷者 855 人、行方不明 85 人、流出家屋 1265 棟など であった。これをうけて、以下のような津波対策が提案された ${ }^{19)}$ 。

1. 住宅を高台に移す。土地利用の総合計画が必要

2. 家をコンクリート造りかモルタル造りにする

3. 土塁・生垣・コンクリート塀・宅地林で宅地を囲むこと

4. 船着き場・貯木場など津波に際して浮遊物源となるおそれのあ る施設は住宅地域から離すこと

5. 広区域の土地利用計画を立てること

石巻地方の津波被害は 1933 年の被害が比較的小さかった地域で 大きく、侍浜では海抜 $3 \mathrm{~m}$ 程度に達した。これは過去 2 回の津波よ りも大きい被害であった。チリ津波後は防潮堤と防波堤を行政が主 導して整備した。

\section{2 震災後の各領域における土地利用}

(1) 浜

震災前の 1955 年に「はえ縄式垂下養殖法」が開発され、チリ津 波前から隣の荻浜で実用化されていた ${ }^{14)}$ が、チリ津波後に漁法の 変化は見られなかった。漁法が変わるのは、養殖業者が増加した
1970 年代である。具体的には、湾内のみで養殖が出来なくなり、 波が比較的荒い湾外でも養殖が出来る「はえ縄式垂下養殖法」が必 要となったためである。漁港部の埋め立ても行われ、防潮堤内部を 各世帯で均等分割して各々の作業場兼漁具置場とし、各世帯の土地

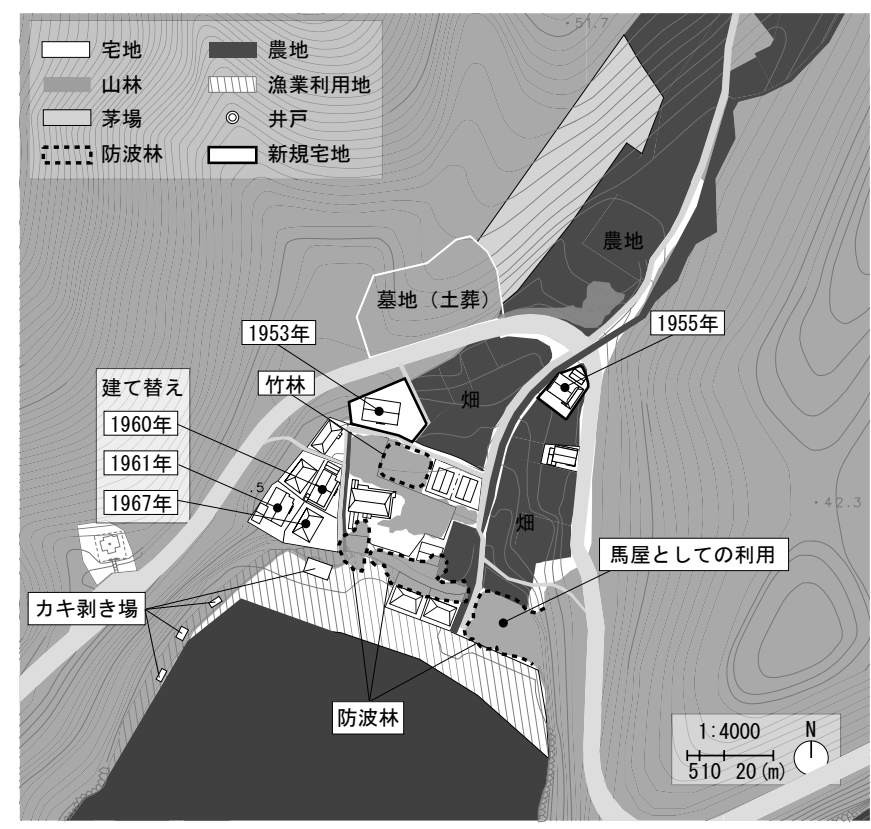

図 9 昭和津波後の家まわりでの土地利用

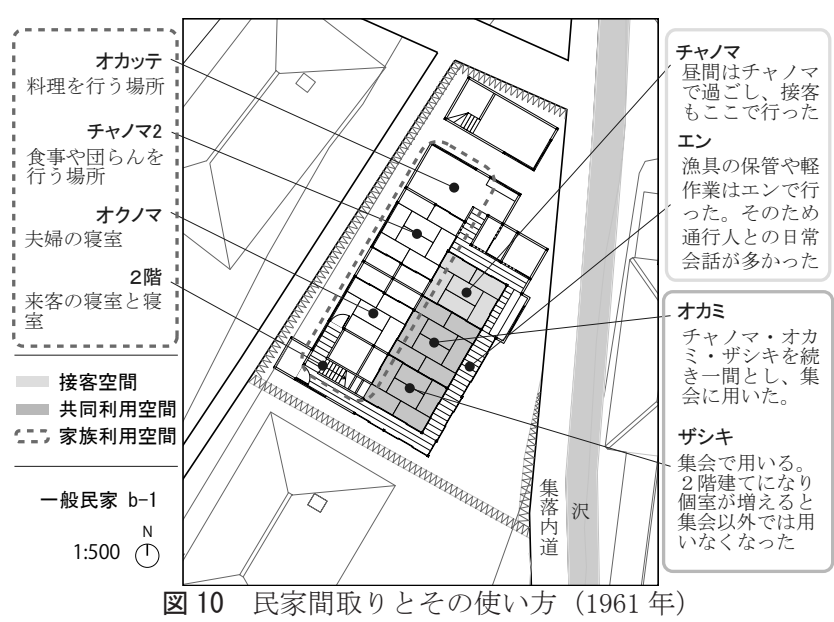

表 7 領域ごとの所有と利 表 8 利用母体と頻度の関係からみ 用の関係 (明治津波後) た土地利用の特徴 (明治津波後)

\begin{tabular}{|c|c|c|c|c|c|c|c|c|}
\hline & 行為 & 土地所有 & 利用母体 & & & \multicolumn{3}{|c|}{ 利用母体 } \\
\hline \multirow[b]{2}{*}{ 浜 } & 磯物 & 集落 & 集落民 & & & 集落民 & 東西住民 & 集落全体 \\
\hline & $\begin{array}{l}\text { 力キ剥き } \\
\text { 作業場 }\end{array}$ & $\begin{array}{l}\text { 地主 } \\
\text { 集落 }\end{array}$ & $\begin{array}{l}\text { 新規参入者 } \\
\text { 各世带 }\end{array}$ & 多 & & $\begin{array}{l}\text { 水汲み } \\
\text { 磯物 }\end{array}$ & エンガワでの & \\
\hline & $\begin{array}{l}\text { 水汲み } \\
\text { 洗濯 } \\
\text { 冠婚葬祭 }\end{array}$ & \begin{tabular}{|l|} 
集落 \\
集落 \\
集落民
\end{tabular} & $\begin{array}{l}\text { 東西住民 } \\
\text { 集落民 } \\
\text { 集落 }\end{array}$ & & 日 & $\begin{array}{c}\text { 洗濯 } \\
\text { 作業場 }\end{array}$ & 世間話 & \\
\hline & $\left\{\begin{array}{l}\text { 祭事 } \\
\text { 世間話 } \\
\text { 民家建設 } \\
\text { 訪問 } \\
\text { 畑仕事. }\end{array}\right.$ & $\begin{array}{l}\text { 集落民 } \\
\text { 集落民 } \\
\text { 集落民 } \\
\text { 集落民 } \\
\text { 各世带 }\end{array}$ & $\begin{array}{l}\text { 集落 } \\
\text { 東西住民 } \\
\text { 集落 } \\
\text { 東西住民 } \\
\text { 東西住民 }\end{array}$ & 頻 & 递 & $\begin{array}{l}\text { 薪拾い } \\
\text { 山菜採り }\end{array}$ & $\begin{array}{l}\text { 他家への訪問 } \\
\text { 畑仕事の協力 }\end{array}$ & \\
\hline & 竹林活用 & 集落 & 各世帯 & & & ; & & 冠婚葬祭 \\
\hline 山 & \begin{tabular}{|l} 
薪拾い \\
山菜採り \\
林道整備 \\
建材利用
\end{tabular} & $\begin{array}{l}\text { 地主 } \\
\text { 地主 } \\
\text { 集落 } \\
\text { 地主 }\end{array}$ & \begin{tabular}{|l} 
集落民 \\
集落民 \\
集落 \\
集落民 \\
\end{tabular} & 少 & & $\begin{array}{cc}\text { 建材利用 } \\
\text { 力キ剥き } \\
\text { 竹林活用 } \\
. \\
\end{array}$ & & $\begin{array}{c}\text { 林道整備 } \\
\text { 民家建設 } \\
\text { 祭事 }\end{array}$ \\
\hline
\end{tabular}


所有を明確化した。

\section{(2) 家まわり}

図 11 で示すように、チリ津波で被害を受けた 1 世帯は高地への 宅地変更を行っている。集落東部にある畑地の宅地化はその後も続 き、家まわりにおける畑の面積は減少していった。1979 年には宅 地化できる畑地を所有していない世帯注3) の分家が、かつての浸水 域に再び家を建てた。低地部への再定住が行われた要因は烟地減少 の他にも存在している。津波の記憶が薄れたこと、防潮堤があった こと、これまで山林整備のために浸水域に立地していた馬屋が必要 なくなったことなどがヒアリングにより確認された。

1960 年代後半のものは続き三間を継承するものが多く、敷地が 小さい場合は 2 階に続き三間を設けたり、軒桁両方向に続き間を持 つようにした。図 12 に示すように、1970 年代後半以降のものはチャ ノマが独立して続き二間となるものが多くみられた。チャノマをよ り個人的な空間として利用し、接客は玄関で行うようになった。

\section{(3) 山林}

1970 年代に入るとガスを利用するようになったため、これまで 続いていた「b. 燃料資源」としての活用がなくなる。続く 1980 年 代には、山間部の畑も植林され県道上部より山林となる。しかしな がら、1980 年代末には林業も行われなくなり、その後は山林の管 理が行われていない。1990 年代には山の役割は「c．キノコや山菜 などの採集」のみとなったが、薪材利用や畑がなくなり山への往来 が減り、徐々に林道を維持できなくなっていった。2000 年代には キノコや山菜を採りに山へ入る人はいなくなったと言われている。

\section{3 土地利用の特徵}

表 9 及び表 10 で示すように、共同利用は浜・家まわり・山林の どの空間でも大きく減少した。これは浜における共同力キ剥き場や 均等分割した作業場でみられるように、集落全体で使うものは集落 の所有とし、個人領域と集落で利用する空間の明確化が進んだこと と山林を利用しなくなったことに起因する。しかしながら、家まわ りでの共同利用は比較的継続されている。オカミ・ザシキの日常的

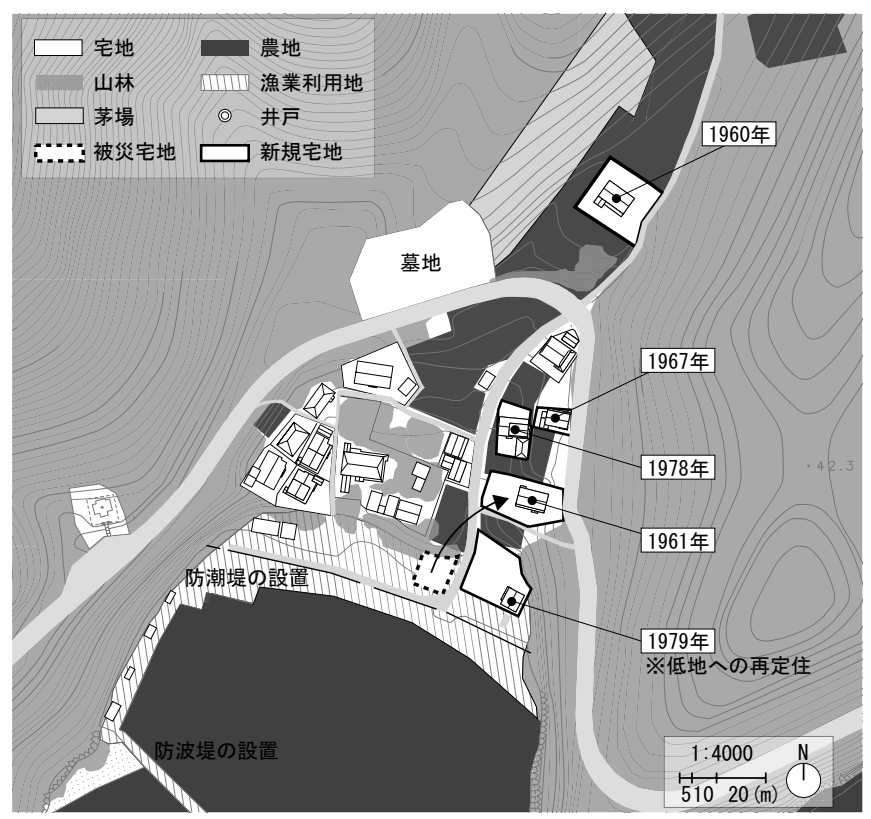

図 11 チリ津波以降の家まわりでの土地利用

な利用頻度は減っても、集落全体で共同利用する場所として続き間 の役割は維持され、人間関係の構築に寄与したものと推察される。 図 13 に集落空間を断面から捉えた図を示寸。1970 年代に、家まわ りではガスの導入により山の利用が減少し、浜ではカキ養殖の効率 化で漁業の生産性が向上した。そして、低地部一再定住する世帯も 現れ、家まわりの領域が浜へ拡大した。

\section{2011 年東日本大震災以降の居住形態}

\section{1 津波被害とその対策}

侍浜での津波波高は $9 \mathrm{~m}$ に達し、明治以降過去 3 回の津波と比較 してその規模は最も大きかった。被害状況は流出家屋 3 軒、流出漁 具倉庫 8 軒、地震による全壊家屋 2 軒である。しかしながら、宅地 の多くが高地にある侍浜の津波被害は、周辺集落と比べて少なかっ た。

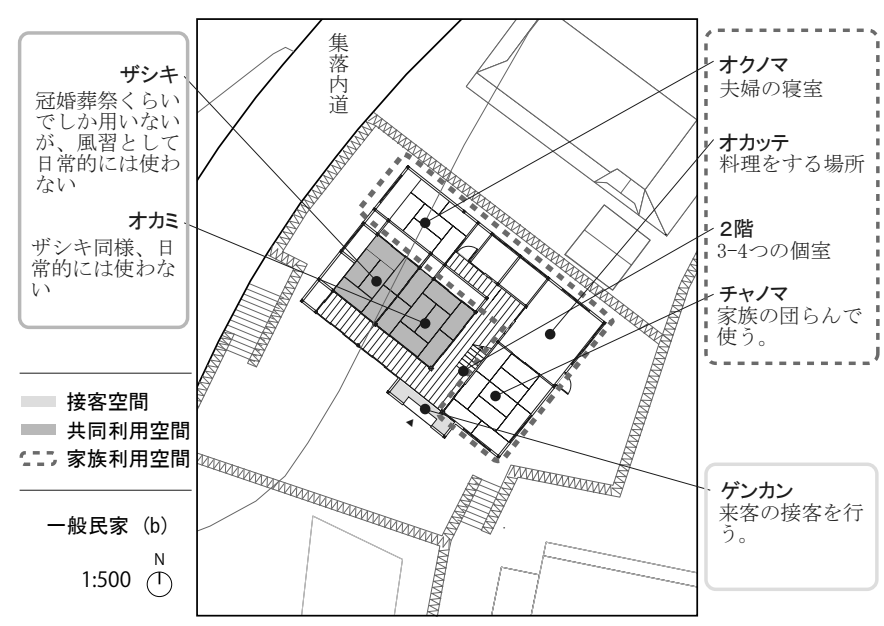

図 12 2間取り民家の使い方（1975 年）

表 9 領域ごとの所有と利 用の関係（チリ津波後）

\begin{tabular}{|c|c|c|c|}
\hline & 行為 & 土地所有 & 利用母体 \\
\hline \multirow{2}{*}{ 浜 } & 磯物 & 集落 & 集落民 \\
\hline & カキキ剥き & 集落 & 各世帯 \\
\hline \multirow{4}{*}{$\begin{array}{l}\text { 家 } \\
\text { 吾 } \\
\text { i }\end{array}$} & 冠婚葬祭 & 集落民 & 集落 \\
\hline & 祭事 & 集落民 & 集落 \\
\hline & 集会所 & 集落 & 集落 \\
\hline & 訪問 & 集落民 & 東西住民 \\
\hline 山 & 山菜採り & 網元 & 集落民 \\
\hline
\end{tabular}

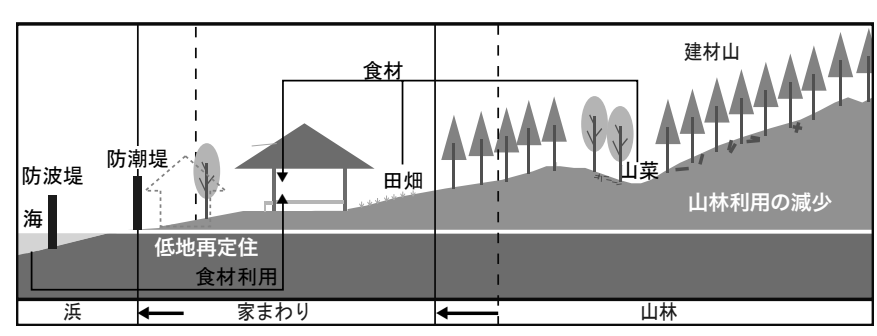

図 13 チリ津波後の集落空間利用 


\section{2 震災後の各領域における土地利用}

(1) 浜

震災後もカキ養殖業を営んでいるが、震災以前からの高齢化も影 響し、カキ養殖業者数が減少した。震災前まで漁業に従事していた 5 世帯のうち 2 世帯が引退した。また、親戚関係にある 2 世帯が共 同で漁業を再開し、跡継ぎのいる 1 世帯がこれまで通り再開した。 (2) 家まわり

図 14 に示寸ように、被害を受けた 3 軒は 1979 年以降にかつての 津波浸水域に建設されたものである。また、2000 年以降集落住民 が減少し空き家が増加してきているが、震災後は空き家になってい た民家を被災した他集落の人に貸し出すものもあった。

(3) 山林

震災以降も山の利用は行われていない。山が雑木林から杉林に なったことで、台風時の土砂崩れが増えたともいわれており、倒れ た木や昔間伐した木材が散乱している状況である。

\section{3 土地利用の特徵}

カキ剥き作業や祭事、民家続き間での冠婚葬祭などは共同で利用 するものだが、それ以外は各世帯ごとでの個別利用がほとんどと なった。

\section{8. 津波対策が集落に与えた影響に関する考察}

侍浜集落には津波被害の軽減を直接的な目的とする、顕在的な津 波対策が各時代に実施されてきたことを示した。明治津波後は図 7 および図 8 に示寸ように被害宅地の高地移転を行い、昭和津波後は 図 9 に示すように防波林を設置し、チリ津波後は図 11 に示すよう に被害宅地の高地移転と防潮堤・防波堤の設置を行った。各津波対 策の実行主体はそれぞれ異なり、防波林は集落民が総出で整備した が、防潮堤・防波堤は行政が主導して行っている。その一方で、直 接的に被害を軽減する効果はなくとも津波対策として機能してい た、潜在的な津波対策として位置づけられる集落の土地利用が存在 していることが明らかになった。震災後の津波対策とその継続状況 を表 11 に示す。侍浜では、明治津波やチリ津波後に高地移転を行っ ているが、その対象地として山林を切り開くのではなく家まわりの 畑を利用した。家まわりの畑は、分家が出る際や災害が起きた際に 宅地化出来る場所としての機能を持ち、家を建てた後、山に新たな 畑地を設けた。また、山林に多くの建材を持つことで、津波被害の ような突発的な災害にも対応できた。さらに、宅地の高地移転後の 低地部を馬屋として利用するなど、被災域を再び宅地としないため の集落の対策が存在していた。こういった姿勢は、必ずしもすべて が津波に直接的に備えている訳ではないが、日常的な生活が津波へ の備えとなる、潜在的な津波対策と捉えることができる。東日本大 震災において被害を受けた世帯はかつての浸水域に建てられたもの であり、潜在的な津波対策の減少がかつての浸水域一の居住を招い た一因であると考えられる。

また、これら潜在的な津波対策は集落の共同管理が背景に存在 することによって成立していたと考えられる。つまり、「山林」に おける共同利用が非常時に建材や畑地を使用可能な状態を維持し、 「浜」における共同漁業は、運命共同体的な協力関係を有していた。 漁業形態が変化し全員で漁業を行わなくなった後も、「家まわり」 では各世帯が祭事や冠婚葬祭を行う続き間を有し、様々な集落行事
を行うことで集落としての協力体制は維持された。このように、生 活空間ごとの共同利用が集落単位での津波対策を潜在的に形成し、 維持していく上で重要なものであったと考えられる。しかしながら、 潜在的な津波対策は、山林利用の減少や集落行事の減少、集まる場 としての続き間の減少などにより、チリ津波後になると徐々に減少 していった。

\section{9. おわりに}

本研究では、遠隔地への移転を行わなかった集落を対象に、度重 なる津波被害とその復興を経験した集落の形成過程に関する文献及 び現地調查を実施した。まず、明治初期の土地利用を「浜」「家まわり」 「山林」という 3 つの空間区分から捉え、その後、過去 4 回の津波 被害とその後の集落における土地利用を、それぞれの時代ごとに整 理し分析した。その結果、集落の津波対策には顕在的なものと潜在 的なものの 2 種類が存在していたことが明らかになった。しかしな がら、ガスの導入に伴う山林利用の減少や生活利便性の向上に起因 する祭事の減少などの変化を経て、潜在的な津波対策を形成してい

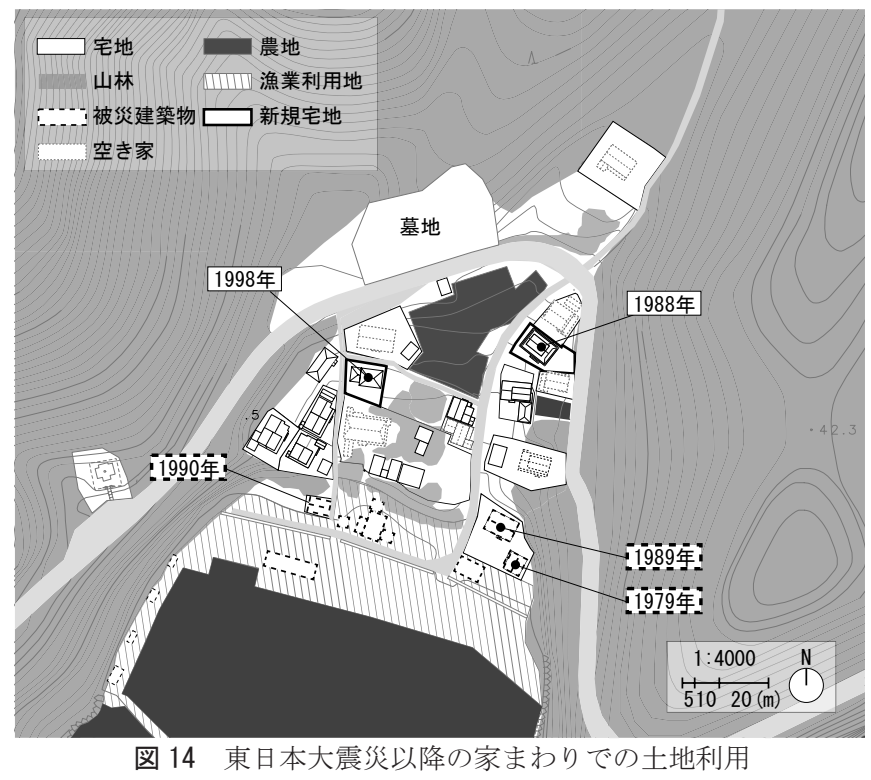

表 11 震災後の津波対策とその継続

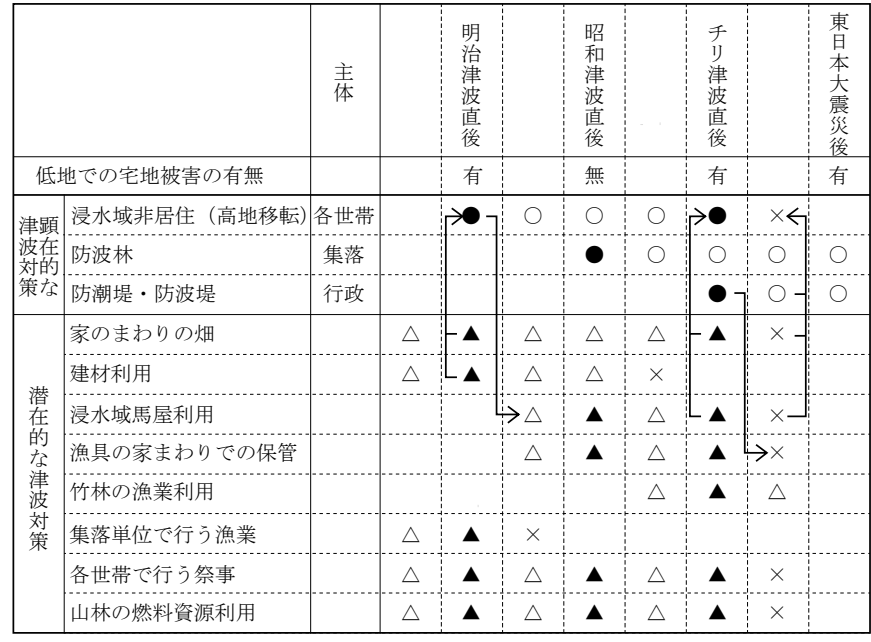

○: 顕在的な津波対策の実施 $\bigcirc$ : 顕在的な津波対策の継続 $\times$ : 津波対策の消失 $\boldsymbol{\Lambda}$ : 潜在的な津波対策として機能 $\triangle$ : 利用の継続 $\leftarrow$ : 直接的な関保 
た集落というまとまりが次第に弱まっていく。同時に、チリ津波以 降は災害対策を行政が担保するようになり、地域住民主体の潜在的 な津波対策から行政主体の顕在的な津波対策に変化した。本研究で 得られた成果から、山と海に囲まれた三陸沿岸の漁村集落における 復興の課題として、防災集団移転促進事業と防潮堤・防波堤の整備 という行政主導の顕在的な津波対策のみに頼るのではなく、潜在的 な津波対策の再構築も重要であるということが指摘できる。例えば、 建材や薪材としての山林資源の再活用や山間地帯の畑利用を行うこ と、家まわりの続き間の継承による住民間コミュニティーの維持な どが具体的な方策の一例として考えられる。

\section{謝辞}

調查に協力して頂いた、侍浜行政区長をはじめとする侍浜集落の 住民の皆さんに感謝の意を表します。

\section{注}

注 1) 侍浜で主に行われていた漁法は、侍浜の地理的条件と明治中期から後 期にかけての隣接する集落の漁法が記載されている文献 13）の内容とヒア リング結果に基づき確認した。侍浜で主に行われていた漁法は「大網」で あったと考えられる。「大網」とは 20 人 25 人が協力して行う定置網漁で、 地主を網元として集落単位で行っていた漁法である。2 月から網の準備を 始め、4月から 9 月にかけてカドイワシを狙った。

注 2）明治初期と大きな変更がなかったため、明治津波以降の共同利用分析 図、共同利用一覧図は割愛した。

注 3) 明治津波後から低地の宅地化が行わる以前の1979 年までは、宅地を設 ける際は本家の畑地を宅地に変更してきていた。1979 年の低地への宅地 化が行われた際、宅地化を行った世帯の本家は畑地を所有していたが、す べての畑地を他家系へ貸し出しているとともに、既に山林の畑地を植林し ていた。そして、貸し出しを受けた他家系は他に畑地を所有していなかっ た。交通の便が悪い当該地区では、日常的な食料を確保する上で最低限の 畑地を確保する必要があった。そのため、畑地の減少が難しかったという 事情がある。

\section{参考文献}

1）山本健司, 宮崎隆昌：沿海集落における生活空間の構成場の特性と「距 離感覚」に関寸る研究, 日本建築学会計画系論文集, No.605, pp.31-38, 2006. 7

2）長坂大: 集落における屋外空間の構成と変遷についての研究-わが国の 現代漁村集落を事例として一, 日本建築学会計画系論文集, No.495, pp. 271-279, 1997. 5

3）小泉正太郎, 三国政勝: 漁業地区における住居及び近隣の空間形成に関 する研究 一その 1 千葉県勝山漁業 集落の調查を通して-, 日本建築学 会論文報告集，No. 312，pp. 123-132，1982.2

4）藤木三千人：沿岸小漁村における漁業形態の変遷と村落構造 - 牡鹿半島
五部裹の事例 -, 東北大学教育学部研究年報, vol. 6, pp. 149-170, 1958

5) 竹内利美, 江馬成也, 藤木利美 : 東北村落と年序組織, 東北大学教育学 部研究年報, vol. 7, pp. 63-172, 1959

6) 山口弥一郎: 津浪常襲地三陸海岸地域の集落移動, 亜細亜大学誌緒学紀要, 人文・社会・自然, vol. 11，1964

7) 村尾修, 礒山星 : 岩手県沿岸部津波常習地域における住宅立地の変遷, 日本建築学会計画系論文集, No. 671, pp. 57-65, 2012.1

8）沼野夏生，菊池義浩：昭和三陸津波による集団移転計画地の実態と今次 津波による被災状況について, 日本建築学会東北支部研究報告集, 計画系 No. 75 , 2012.6

9) 前田昌弘, 高田光雄, 神吉紀世子：世帯間関係の組み合わせパタンと住 宅敷地所有・利用関係の分析 -インド洋津波後のスリランカにおける住宅 移転をともなう再定住に関する研究 その 2 - , 日本建築学会計画系論文 集 No.661，pp. 617-624，2011. 3

10）嶋村清：湾地形と津波高の関係についての研究 -平成 23 年東北地方 太平洋沖地震における津波の地形学的研究-, 東海大学紀要産業工学部 4 , pp. 1-8, 2011

11）地理地殼活動研究センター 小荒井衛, 岡谷隆基, 中埜貴元, 神谷泉 : 東日本大震災における津波浸水域の地理的特徵, 国土地理院時報, 第 122 集（特集：東日本大震災）,pp. 97-110, 2011

12) アーキエイド :ディテール4月号別冊 浜からはじめる復興計画 牡鹿・ 雄勝・長清水での試み, 彰国社, 2012

13) 東北歴史資料館 : 三陸沿岸の漁村と漁業習俗（上巻）第 1 章宮城県石巻 市月浦，東北歴史資料館，1984

14）水産技術総合センター：宮城県の伝統的漁具漁法 7 養殖編（かき）, http://www. pref. miyagi. jp/soshiki/mtsc/kaki-mokuji.html, 2013. 10. 08 参照

15）宮城県教育委員会 : 宮城県文化財調查報告書第 60 集 歴史の道調査報告 書, 1979

16）国土地理院：国土変遷アーカイブ, http://kindai.ndl.go.jp/info :ndljp/pid/1121166，2013.10.08 参照

17）災害防災会議 災害教訓の継承に関する専門調査会：1896 年明治三陸 地震津波報告書, 内閣府, 2005, http://www. bousai. go. jp/kyoiku/ kyokun/kyoukunnokeishou/rep/1896-mei ji-sanrikuJISHINTSUNAMI/index. html, 2013.10.08 参照

18）中央気象台：三陸沖強震及津浪報告, 中央気象台, 1933, http:// kindai.ndl. go. jp/info:ndljp/pid/1121166, 2013. 10.08 参照

19）気仙沼地区調査委員会：チリ地震記念三陸津波誌 1960 , 気仙沼地区調 查委員会, 1960, http://tsunami-dl. jp/document/064, 2013.10.08 参照 20）石巻市史編さん委員会：石巻の歴史 第二巻 通史編, 石巻市史編さん 委員会, 1989

21）石巻市史編さん委員会 : 石巻の歴史 第三巻 民俗・生活編, 石巻市史 編さん委員会，1989

22) 石巻市史編さん委員会: 石巻の歴史 第四巻 教育・文化編,pp. 977-978, 石巻市史編さん委員会 , 1989

23）内務大臣官房都市計画課：三陸津浪に因る被害町村の復興計画報告報 告, 1934

（2013年10月 8 日原稿受理，2014年 2 月10日採用決定） 